\title{
Perilaku Warga Peduli AIDS terhadap Penanggulangan HIV dan AIDS Di Kota Kupang
}

\author{
Wenzel Fernandez ${ }^{1}$, Imelda F.E. Manurung ${ }^{2}$, Sarci M. Toy ${ }^{3}$, Honey I. \\ Ndoen 4 \\ 1,2,3,4)Fakultas Kesehatan Masyarakat Universitas Nusa Cendana \\ Email: imelda.manurung@staf.undana.ac.id
}

\begin{abstract}
The AIDS Tackling Committee (KPA) of Kupang City has been running several programs handling over the AIDS and HIV. One of the program is involving ordinary member of the society through AIDS Care Community Member. This research aim is to describe knowledge, attitude, and behavior of AIDS Care Community Members towards HIV and AIDS Tackling Program. This research is a survey, descriptive in nature. It was held from October 2017 to March 2018. The research population is 625. By using Slovin formula and simple random sampling technique, the sample is 93 . The research results are as follows: the majority of the community member possessed a good knowledge $(74 \%)$, all of the community members (100\%) showed a positive attitude on the effort and $60,2 \%$ of the members of the community have conducted supportive acts towards the effort. Therefore, it is suggested that, there should be some upgrading's on cadres capacity, especially their active involvement in mobilizing the society to conduct some supportive acts. Finally, it is expected that the overall society participation in tackling HIV and AIDS should be uplifted.
\end{abstract}

\section{Keywords: AIDS Care Community Members, Behavior}

Salah satu program penanggulangan HIV dan AIDS yang dicanangkan oleh KPA Kota Kupang adalah pelibatan masyarakat umum melalui Warga Peduli AIDS. Tujuan penelitian adalah mengetahui gambaran pengetahuan, sikap, dan tindakan warga peduli AIDS terhadap upaya penanggulangan HIV dan AIDS Kota Kupang. Jenis penelitian ini adalah penelitian survei deskriptif, waktu penelitian dilaksanakan dari bulan Oktober sampai dengan bulan Maret 2018. Besar populasi penelitan 625 orang dan besar sampel 93 orang yang diperoleh dari rumus Slovin. Teknik pengambilan sampel yang digunakan adalah teknik simple random sampling. Hasil penelitian menunjukkan gambaran pengetahuan Warga Peduli AIDS terhadap penanggulangan HIV dan AIDS mayoritas Warga Peduli AIDS berpengetahuan baik (74,2\%). Gambaran sikap Warga Peduli AIDS terhadap Penanggulangan HIV dan AIDS semua Warga Peduli AIDS bersikap positif (100\%). Gambaran tindakan Warga Peduli AIDS terhadap Penanggulangan HIV dan AIDS mayoritas Warga Peduli AIDS sudah melakukan tindakan yang mendukung penanggulangan HIV dan AIDS $(60,2 \%)$. Diharapkan agar adanya peningkatan kapasitas kader-kader mengenai keterlibatan aktif dalam upaya memobilisasi masyarakat mengenai tindakan- tindakan Peduli AIDS, serta bagi masyarakat untuk meningkatkan partisipasi dalam upaya menanggulangi AIDS di wilayah Warga Peduli AIDS.

Keyword: Perilaku, Warga, Peduli, AIDS 


\section{PENDAHULUAN}

Kasus HIV dan AIDS merupakan fenomena gunung es, dengan jumlah orang yang dilaporkan jauh lebih sedikit dibandingkan dengan yang sebenarnya. Hal ini terlihat dari jumlah kasus AIDS yang dilaporkan setiap tahunnya sangat meningkat secara signifikan. Di seluruh dunia, setiap hari diperkirakan sekitar 2000 anak di bawah 15 tahun tertular HIV dan sekitar 1400 anak di bawah usia 15 tahun meninggal dunia, serta menginfeksi lebih dari 6000 orang berusia produktif (Pusat Data dan Informasi Kementerian Kesehatan RI, 2014).

Kejadian penyakit HIV dan AIDS di Provinsi Nusa Tenggara Timur (NTT) berdasarkan data Komisi penanggulangan AIDS (KPA) Kota Kupang 2015, jumlah kasus HIV dan AIDS di Kota Kupang dari tahun 2000 sampai Desember 2015 sebanyak 784 kasus yakni HIV 560 kasus dan AIDS 224 kasus. Perkembangan kasus HIV dan AIDS pada tahun 2011 terdapat 57 kasus HIV dan 8 kasus AIDS, tahun 2012 terdapat 52 kasus HIV dan 19 kasus AIDS, tahun 2013 terdapat 120 kasus HIV dan 40 kasus AIDS, tahun 2014 terdapat 79 kasus HIV dan 29 kasus AIDS, hingga pada September 2015 tercatat 74 kasus HIV dan AIDS sebanyak 53 kasus. Morbiditas Kasus dikota Kupang menurut jenis kelamin dari tahun 2000 hingga tahun 2016 terjadi lebih tinggi pada laki-laki yaitu sebanyak 593 kasus dan pada perempuan sebanyak 422 kasus dimana paling tinggi terjadi pada golongan umur 25-49 tahun (KPAD Kota Kupang, 2016).

Warga Peduli AIDS (WPA) adalah gerakan partisipasi masyarakat dalam membangun kesadaran kritis untuk menciptakan lingkungan hidup yang sehat dan sejahtera. WPA dibentuk dalam upaya pencegahan dan penanggulangan HIV dan AIDS yang memerlukan dukungan masyarakat luas, gerakan masyarakat tersebut dibentuk berdasarkan tingginya angka penyebaran HIV dan AIDS yang dapat menurunkan angka harapan hidup, terlebih penyebaran terjadi pada proporsi kelompok umur yang lebih muda (KPA Nasional, 2008).

Proses yang dilakukan masyarakat dalam Warga Peduli AIDS akan dimulai dari sistem identifikasi potensi, perumusan masalah, menentukan prioritas masalah, menentukan rencana kegiatan dan program serta evaluasi dan monitoring. Semua proses tersebut dilakukan dengan metode partisipatif (KPA Nasional, 2008). 
Upaya pencegahan HIV dan AIDS di Kota Kupang berbasis gerakan masyarakat diwujudkan dalam bentuk Warga Peduli AIDS (WPA) yang terdiri dari berbagai komponen dalam suatu lingkungan masyarakat baik di tingkat Desa, Kelurahan, Rukun Warga (RW), Dusun, Blok dan tingkatan yang sejenis yang ada di suatu lingkungan tempat tinggal. Tugas utama Warga Peduli AIDS adalah menggerakan masyarakat untuk ikut serta terlibat secara langsung dalam upaya pencegahan dan penanggulangan HIV dan AIDS (Komisi Penanggulangan AIDS Nasional, 2008).

Pengetahuan warga peduli AIDS sangat erat hubungannya dengan penanggulangan HIV dan AIDS dalam mendukung pengendalian penyakit HIV dan AIDS dimana warga yang memiliki pendidikan cukup akan memberikan pengetahuan yang baik tentang penyakit HIV dan AIDS sehingga memungkinkan untuk melakukan upaya pencegahan secara dini terhadap diri sendiri, keluarga maupun upaya sosialisasi kepada orang lain.

Sikap warga peduli AIDS dalam menjaga dirinya agar terhindar dari infeksi penyakit HIV dan AIDS juga berpengaruh karena sikap warga menunjang perilaku warga dalam meng- hadapi kejadian penyakit HIV. Sikap warga adalah bagaimana warga menerima, merespon, menghargai dan bertanggung jawab terhadap kejadian penyakit HIV dan AIDS sehingga didapatkan sikap yang utuh dalam melakukan upaya penanggulangan HIV dan AIDS.

Perilaku warga peduli AIDS merupakan perwujudan sikap warga menjadi suatu perbuatan nyata. Tindakan merujuk pada persepsi warga terhadap penanggulangan penyakit HIV dan AIDS kemudian meresponnya melalui pencegahan yang sesuai dan mulai membiasakan diri dengan kebiasaan hidup bersih dan sehat dengan tujuan meminimalkan risiko terjangkit infeksi penyakit HIV dan AIDS, dan pada akhirnya membuat suatu tindakan yang sudah termodifikasi dalam pengendalian penyakit HIV dan AIDS. Untuk itu penelitan ini bertujuan untuk melihat bagaimana perilaku WPA dalam penanggulangan HIV dan AIDS.

\section{METODE PENELITIAN}

Jenis penelitian yang digunakan adalah penelitian survei deskriptif yang dilakukan terhadap sekumpulan objek yang biasanya bertujuan untuk melihat gambaran fenomena (termasuk kesehatan) yang terjadi di dalam suatu populasi tertentu 
(Notoatmodjo, 2012). Pada umumnya survei deskriptif digunakan untuk membuat penilaian terhadap suatu kondisi dan penyelenggaraan suatu program di masa sekarang, kemudian hasilnya digunakan untuk menyusun perencanaan perbaikan program tersebut. Survei deskriptif juga dapat didefinisikan sebagai suatu penelitian yang dilakukan untuk mendeskripsikan atau menggambarkan suatu fenomena yang terjadi di dalam masyarakat.

Dalam bidang kesehatan masyarakat survei deskriptif digunakan untuk menggambarkan atau memotret masalah kesehatan serta yang terkait dengan kesehatan sekelompok penduduk atau orang yang tinggal dalam komunitas tertentu (Notoatmodjo, 2012). Lokasi penelitian ini terletak di Kelurahan Sikumana Kota Kupang. Lokasi ini dipilih karena mudah dijangkau dan arena lokasi ini terdapat kasus HIV dan AIDS. Waktu penelitian dilaksanakan dari bulan Oktober 2017 sampai dengan bulan Maret 2018. Populasi penelitian adalah masyarakat di Kelurahan Sikumana Kota Kupang yang telah mendapatkan pendampingan oleh WPA yang berjumlah 625 orang. Sampel dalam penelitian ini adalah masyarakat Kota Kupang yang telah mengikuti penyuluhan yang dilakukan oleh kader WPA yaitu sebanyak 93 orang. Teknik pengambilan sampel adalah teknik simple random sampling. Besar sampel dalam penelitian ini ditentukan dengan menggunakan rumus Slovin.

\section{HASIL DAN PEMBAHASAN Hasil}

Hasil penelitian ini menyajikan data karakteristik repsonden, pengetahuan, sikap dan tindakan responden dalam penanggulangan HIV dan AIDS. Jumlah respondeni lebih banyak berjenis kelamin perempuan $(61,3 \%)$. karakteristik responden berdasarkan umur paling banyak adalah responden dengan kelompok umur $>30$ tahun sebanyak $74,2 \%$.

Pada tabel 1 (hal. 487) menunjukkan bahwa mayoritas Warga Peduli AIDS berpengetahuan baik (74,2\%). Warga memiliki pengetahuan yang baik mengenai singkatan HIV, pengertian HIV, singkatan AIDS, penyebab AIDS, dan cara penularan HIV. 
Tabel 1. Karakteristik dan Perilaku WPA dalam Penanggulangan HIV dan AIDS

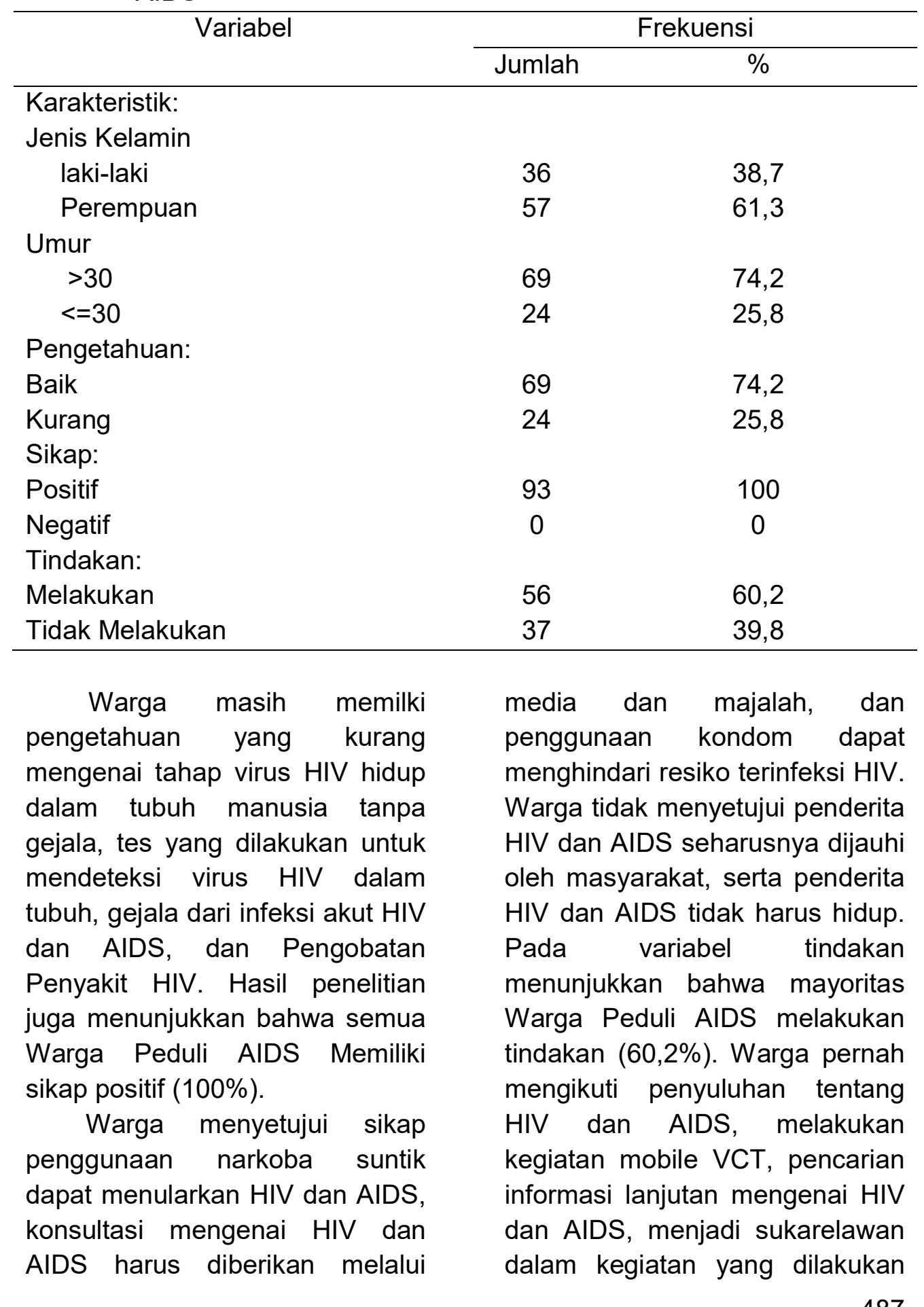


oleh kader WPA, dan melakukan upaya sosialisasi mengenai upaya penanggulangan dan pencegahan HIV dan AIDS.

Green LW dan Marshall W. Kreuter (2004) menyatakan penyebab perilaku seseorang adalah karena adanya alasan pemikiran dan perasaan dalam bentuk pengetahuan. Pengetahuan dapat membentuk keyakinan tertentu sehingga seseorang berperilaku sesuai dengan keyakinan tersebut.

Pengetahuan yang baik mengenai singkatan HIV dan AIDS serta pengertian dari HIV dan AIDS menjadi bukti bahwa masyarakat menerima dan memahami informasi yang diberikan oleh kader Warga Peduli AIDS. Informasi yang diterima oleh masyarakat perlu dilakukan secara terus menerus oleh kader Warga Peduli AIDS agar pengetahuan masyarakat semakin luas dan upaya pencegahan Penyakit HIV dan AIDS di Kelurahan Sikumana semakin terlihat

Dalam rangkuman pertanyaan kategori pengetahuan yang berjumlah 15 pertanyaan, dapat dilihat bahwa pada beberapa pertanyaan dengan tingkat kesulitan rendah memiliki poin benar lebih banyak dibandingkan dengan pertanyaan dengan tingkat kesulitan yang lebih tinggi. Hal ini mungkin disebabkan karena tingkat pendidikan dari responden sendiri yang masih rendah sehingga dirasa sulit untuk memahami informasiinformasi yang lebih kompleks mengenai HIV dan AIDS.

Hasil penelitian menunjukan bahwa dari 93 responden, sebanyak 69 responden $(74,2 \%)$ sudah memiliki pengetahuan yang baik terhadap penanggulangan HIV dan AIDS di Kota Kupang. Hasil Penelitian ini juga sejalan dengan penelitian yang dilakukan Silalahi (2008) dan Juliatika (2011) yang menunjukan bahwa tingkat pengetahuan secara signifikan berpengaruhi terhadap praktik pencegahan. Penelitian ini juga sejalan dengan penelitian yang dilakukan oleh Putu (2015) di Kelurahan Alak Kota Kupang yang menunjukan bahwa tingkat pengetahuan Masyarakat di kelurahan Alak kota Kupang berpengaruh terhadap Tindakan Pencegahan.

Pada variabel sikap menunjukan bahwa dari 93 responden, semuanya (100\%) memiliki nilai yang menunjukkan sikap positif terhadap penanggulangan HIV dan AIDS di Kota Kupang. Hal ini timbul karena adanya keyakinan atau kepercayaan dalam diri sebagai akibat dari pengetahuan yang dimiliki. Pengetahuan masyarakat yang baik mengenai HIVIAIDS akan menimbulkan suatu 
kesadaran, dan suatu ketertarikan, sehingga timbul suatu pertimbanganpertimbangan yang baik dan yang buruk mengenai bahayanya HIV dan AIDS. Hal tersebut akan menghasilkan suatu sikap yang lebih baik sehingga Warga Peduli AIDS mampu berperilaku sesuai dengan pengetahuan, kesadaran dan sikapnya untuk melindungi diri dari virus HIV. Hasil penelitian ini sejalan dengan penelitian yang dilakukan Silalahi (2008) dan Juliatika (2011) yang menunjukkan bahwa ada hubungan antara sikap dengan praktik pencegahan.

Tindakan Warga Peduli AIDS merupakan perwujudan dari pengetahuan yang didapat serta sikap yang dimiliki oleh masyarakat Kelurahan Sikumana yang menjadi bukti nyata dalam upaya penanggulangan HIV dan AIDS di Kelurahan Sikumana. Pertanyaan variabel tindakan yang diberikan pada masyarakat Kelurahan Sikumana meliputi keaktifan dalam mengikuti kegiatan penyuluhan yang dilakukan oleh WPA dan Keaktifan responden dalam mengikuti kegiatankegiatan lain yang dilakukan oleh petugas atau kader WPA dalam hal ini: mengikuti mobile VCT, menjadi sukarelawan dalam kegiatan, dan aktif dalam diskusi yang dilakukan oleh kader WPA.
Pada variabel tindakan menunjukkan bahwa sebagian besar responden memiliki tindakan yang positif mengenai penanggulangan HIV dan AIDS $(60,2 \%)$. Dalam hal ini tindakan responden mengenai penyuluhan HIV dan AIDS, kegiatan lanjutan yang dilakukan kader WPA sehubungan dengan penanggulangan HIV dan AIDS, keaktifan partisipasi dalam kegiatan penyuluhan serta diskusi yang dilakukan oleh kader WPA, pemeriksaan mobile VCT yang dilakukan oleh kader WPA secara rutin, kegiatan yang melibatkan ODHA, penggunaan alat kontrasepsi dalam berhubungan seksual, dan kewajiban kader WPA dalam sosialisasi mengenai upaya penanggulangan dan pencegahan HIV dan AIDS.

\section{SIMPULAN}

Komponen perilaku yang terdiri atas pengetahuan warga peduli AIDS terhadap penanggulangan HIV dan AIDS di Kota Kupang tahun 2017 adalah mayoritas pengetahuan warga peduli AIDS memiliki pengetahuan baik $(74,2 \%)$, sikap positif $100 \%$ terhadap penanggulangan HIV dan AIDS, dan sebanyak 56 responden $(60,2 \%)$ sudah melakukan tindakan yang mendukung Penanggulangan HIV dan AIDS. 
Hasil penelitian ini dapat dijadikan sumber referensi untuk menentukan variabel lain dalam penelitian lanjutan mengenai Warga Peduli AIDS. Bagi kader Warga Peduli AIDS Diharapkan dapat meningkatkan kapasitas dari kader-kader yang berada pada wilayah Warga Peduli AIDS mengenai keterlibatan aktif dan upaya memobilisasi masyarakat mengenai tindakan-tindakan peduli AIDS.

\section{DAFTAR PUSTAKA}

Budiman, A.R. 2013. Kapita Selekta Kuesioner Pengetahuan Dan Sikap Dalam Penelitian Kesehatan. Jakarta: Salemba Medika.

DITJEN PP dan PL DPKES RI 2014. Statistik kasus HIV dan AIDS di indonesia. Ditjen PP dan PL DEPKES RI. Jakarta.

Green, Chris. 2013. Pengobatan untuk AIDS: Ingin Mulai?.Jakarta: Yayasan Spiritia.

2013. HIV \& TB. Jakarta: Yayasan Spiritia.

Juliastika, Grace E dan Budi T. 2011.

Hubungan

Pengetahuan tentang

HIVIAIDS dengan Sikap dan

Tindakan Penggunaan

Kondom Pria pada Wanita Pekerja Seks di Kota Manado. FKM. Universitas Sam Ratulangi Manado.
KPA Nasional. 2008, Warga Peduli AIDS Perwujudan Partisipasi Masyarakat dalam Penanggulangan HIV dan AIDS, Jakarta

KPA Kota Kupang. 2016. Komisi Penanggulangan AIDS Kota Kupang. Kupang

KPAD Kota Kupang. 2016. Komisi Penanggulangan AIDS Daerah Kota Kupang. Kupang

Lerik, M.D.Ch. 2008. Dasar Psikologi. Kupang: Undana Press.

Notoatmodjo, Soekidjo. 2012. Metodologi Penelitian Kesehatan. Jakarta: Rineka Cipta. 2010. Promosi Kesehatan Teori dan Aplikasi. Jakarta: Rineka Cipta 2013. Promosi Kesehatan dan Perilaku Kesehatan. Jakarta: Rineka Cipta.

Noor, Nur Nasry. 2013. Pengantar Epidemiologi Penyakit Menular. Jakarta: Rineka Cipta.

Nursalam. 2007. Asuhan Keperawatan Pada Pasien Terinfeksi HIV dan AIDS. Jakarta: Salemba Medika.

Peraturan Menteri Kesehatan Republik Indonesia nomor 21 Tahun 2013 tentang Penanggulangan HIV dan AIDS. Jakarta

Pusat Data Dan Informasi Kementerian Kesehatan RI. 2014. Info Datin (Situasi Dan Analisis HIV AIDS). Jakarta. Diunduh dari www.pusdatin.kemkes.go.id/ 
article/view/17020100001/sit
uasi-penyakit-hiv-aids-di-
indonesia.html pada tanggal
18 desember 2017 jam
18.35 WITA 18.35 WITA.

Silalahi R.E. 2008. Pengaruh Faktor Predisposisi, Pendukung dan Penguat Terhadap Tindakan Pekerja Seks Komersial (PSK) Dalam Pengunaan Kondom Untuk Mencegah HIVIAIDS di Lokalisasi Tileju Pekanbaru tahun 2008. Tesis. Sumatra Utara: Universitas Sumatra Utara. http://www.respository.usu.a c.id [16 Januari 2017]

Siregar, F.A. 2004. Pengenalan dan Pencegahan AIDS. Fakultas Kesehatan Masyarakat Universitas Sumatra Utara Press.

Sugiyono, 2013. Metode Penelitian Kuantitatif Kualitatif dan R\&D. Bandung: Alfabeta. 